Review Article

\title{
Glutathione as a Crucial Modulator of Phytohormone Signalling During Pathogen Defence in Plants
}

\author{
RIDDHI DATTA $^{1, *}$ and SHARMILA CHATTOPADHYAY ${ }^{2}$ \\ ${ }^{1}$ Department of Botany, Dr. APJ Abdul Kalam Government College, New Town, Rajarhat, Kolkata 700 \\ 156, India \\ ${ }^{2}$ Plant Biology Laboratory, CSIR-Indian Institute of Chemical Biology, 4, Raja S. C. Mullick Road, \\ Kolkata 700032, India
}

(Received on 30 October 2017; Revised on 17 December 2017; Accepted on 07 February 2018)

\begin{abstract}
Plant's resistance to different stress factors is regulated by a complex signalling network which connects the individual signalling pathways, enabling them to fine tune their defence response. For more than last two decades, glutathione (GSH) is gradually gaining importance as a crucial player in this network. The present review summarizes the central role of GSH in modulating plant's defence response to biotic stress, specially emphasizing the molecular mechanism of these regulations. Several transgenic approaches to constitutively enhance GSH levels have been followed and in most cases, these transgenic plants exhibited enhanced biotic stress tolerance. The post 2000 era envisaged a mechanistic approach in this field and GSH has been shown to modulate the defence signalling network by cross-communication with several stress-related phytohormones. GSH imparts stress tolerance against biotrophic infection via NPR1-dependent salicylic acid (SA) mediated pathway. GSH regulates SA accumulation at the level of isochorismate synthetase 1 (ICS1) expression and can also act in NPR1-independent pathway. A synergistic GSH-ethylene (ET) interplay during necrotrophic infection has also been reported. It has been demonstrated that GSH induces ET biosynthesis by modulating transcriptional and posttranscriptional regulations of its key enzymes. The cross-talk of GSH with jasmonic acid (JA) and abscisic acid (ABA) in alleviating stress has been reported as well. However, mechanistic details of the interaction between GSH and JA or ABA signaling pathways are not elucidated in details.
\end{abstract}

Keywords: Glutathione; Phytohormone Signalling; Pathogen Defence; Salicylic Acid; Ethylene; Jasmonic Acid

\section{Introduction}

Plants in their natural environment are continuously being threatened by a range of stress factors, including invasion by microbial pathogens, herbivorous insects as well as various abiotic stress conditions. Being immobile, plants have to respond to each of these attackers in a rapid and effective way in order to ensure survival. Plant's resistance to different stress factors is a multifaceted regulatory network which links the various signalling pathways thus enabling them to fine tune their defence responses. Previous studies also envisaged that plant's responses to various stress factors are regulated by multiple signalling pathways. A perfect synchronization of these pathways switches on the transcription of appropriate defence related genes and their downstream machinery ultimately helping the system to tide over unfavourable conditions. It has been welldocumented that an interconnecting signalling network, comprising the salicylic acid (SA), ethylene (ET) and jasmonic acid (JA) mediated signalling pathways, constitute the basic defence response strategy in plants (Glazebrook, 2005; Klessig et al., 2000; Loake and Grant, 2007; Pieterse et al., 2009; Thomma et al., 1998; van Loon et al., 2006). Glutathione (GSH; $\gamma-$ glutamylcysteinyl glycine) is a low molecular weight non-protein tripeptide which is found in nearly all prokaryotic as well as eukaryotic cells. GSH represents the major pool of non-protein reduced

*Author for Correspondence: E-mail: riddhi.bot@gmail.com 
sulphur and plays important roles in cell function and metabolism (Kunert and Foyer, 1993). It is gradually gaining importance as a vital player in this network and plays critical roles in combating biotic and abiotic stresses (Ghanta and Chattopadhyay, 2011).

This tripeptide thiol is a multifunctional metabolite and has drawn significant attention due to its wide distribution in most living organisms, abundance, broad redox potential and unique structural properties. The stability and ability of GSH to function as a cellular reductant has been derived from the single thiol group in the central cysteine. Along with ascorbate, GSH is considered as one of the most abundant redox couples in plant cells (May et al., 1998). It has largely been reported for more than two decades that GSH plays a crucial role in cellular processes including development, growth and adverse environmental responses in plants. Abiotic stresses like extreme temperatures, heavy metal contaminated soils, drought, salinity or air pollutants lead to the generation of reactive oxygen species (ROS) and alter the intracellular redoxhomeostasis perturbing cellular physiology (Ogawa, 2005; Galant et al., 2011). Plants generally respond to such conditions by producing GSH which acts as an antioxidant by quenching ROS. The ascorbate-GSH cycle that eliminates peroxides plays an important role in this respect (Noctor and Foyer, 1998). GSH also participates in the detoxification of a range of xenobiotics, herbicides, heavy metals and air pollutants like sulphur dioxide and ozone (Grill et al., 1989; May et al., 1998). GSH plays a critical role in biotic stress and its management as well (Dubreuil-Maurizi and Poinssot, 2012; Parisy et al., 2007). In fact, a direct link between the biosynthesis of GSH and the expression of defence related genes has been reported in Arabidopsis (Ball et al., 2004). Though the participation of GSH in plant responses to stress has long been reported (Dron et al., 1988; Wingate et al., 1988), yet the underlying molecular mechanism is still being explored.

\section{GSH as a Central Regulator in Biotic Stress Tolerance}

It has been demonstrated that significant changes in the GSH levels occur in the cells adjacent to the site of attempted pathogen ingress. This altered GSH levels then play an important role in regulating the induced defence response including the expression of genes such as glutathione-S-transferases (GSTs) (Jabs et al., 1996; Levine et al., 1994; Mauch and Dudler, 1993) and glutathione peroxidases (GPX) (Levine et al., 1994). Incompatible plant-pathogen interactions generate reactive oxygen species (ROS) and other products of lipid peroxidation which are detoxified by both GST and glutathione reductase (GR). It has been reported that during compatible barley-barley powdery mildew interactions activation of various antioxidative enzymes like GSTs and the ascorbate-GSH cycle occur presumably to lessen the detrimental effects of oxidative stress. On the other hand, these antioxidative reactions are either not activated or are only slightly activated in case of incompatible interactions (El-Zahaby, 1995). In general, pathogen invasion leads to enhanced accumulation of GSH in the cells which also increases the GSH/GSSG ratio and ultimately switches on the downstream defence related signalling cascade.

A transgenic approach to overexpress different GSH related genes in plants to constitutively enhance the GSH levels has widely been followed (Gomez et al., 2004; Gullner et al., 2001; Noctor et al., 1998; Xiang et al., 2001; Zhu et al., 1999). In most cases, these transgenic plants exhibited enhanced stress tolerance. While most of these transgenic plants displayed no phenotypic abnormalities, some suggested a variation. In one such study, transgenic tobacco plants were found to develop severe necrosis due to a hypersensitive response (HR) by overexpressing the $\gamma$-ECS enzyme (Creissen et al., 1999). This is perhaps because an excessive accumulation of GSH in the tissue led to oxidative stress. It has been reported that oxidative stress of intracellular origin can trigger HR and the excessive GSH redox potential (or GSSG accumulation) may lead to the activation of genetically programmed cell suicide pathways in the transgenic plants. This explanation is further supported by the fact that intracellular oxidative stress associated with GSSG accumulation can trigger the HR-like lesion formation (Chamnongpol et al., 1998; Smith et al., 1984; Willekens et al., 1997).

The A. thaliana cad2-1 and raxl-1 mutants have mutations in the GSH biosynthesis enzyme. Ball et al., (2004) reported that a changed GSH metabolism in these mutants leads to an alteration in the expression of 32 stress responsive genes. Another A. thaliana camalexin deficient mutant, pad2-1, was 
isolated in the 1900 s and was demonstrated to be susceptible to Pseudomonas syringaeas well as $P$. brassicae infections (Glazebrook and Ausubel, 1994; Glazebrook et al., 1997). About a decade later, it was demonstrated that the disease susceptibility of this mutant was not due to camalexin deficiency but due to a mutation in the GSH biosynthetic pathway gene and consequent GSH depletion (Parisy et al., 2007). The pad2-1 mutant again displayed decreased resistance to the feeding of insect larvae and this effect has been linked to decreased accumulation of glucosinolates (Schlaeppi et al., 2008). This susceptibility can be rescued by supplementation with exogenous GSH but not with other disulphide reductants like dithiothreitol (Schlaeppi et al., 2008). It has subsequently been reported that formation of the glucosinolatethioglucose moiety encompasses a GSH-conjugate intermediate which is metabolized by a $\gamma$-glutamyl peptidase, GGP (Geu-Flores et al., 2009). Also, this GSH depleted mutant is deficient in camalexin because camalexin synthesis requires GSH as a precursor (Böttcher et al., 2009; Su et al., 2011). In fact, synthesis of both camalexin and glucosinolates involve formation and metabolism of GSH-conjugate

Table 1: Different host-pathogen systems where a defensive role of GSH has been reported

\begin{tabular}{|c|c|c|}
\hline Pathogen & Host plant & Reference \\
\hline Fusarium oxysporum & Cucumis melo and Lycopersicon esculentum & Bolter et al., 1993 \\
\hline Drechslera avenae and Drechslera siccans & Avena sativa & Gönner and Schlösser 1993 \\
\hline Erysiphe graminis & Triticum aestivum & Mauch and Dudler 1993 \\
\hline Erysiphe graminis & Hordeum vulgare & El-Zahaby 1995 \\
\hline Cladosporium fulvum & Lycopersicon esculentum & May et al., 1996 \\
\hline Tobacco mosaic virus & Nicotiana tabacum & Fodor et al., 1997 \\
\hline Pseudomonas syringae and P. brassicae & Arabidopsis thaliana & $\begin{array}{l}\text { Glazebrook and Ausubel 1994; } \\
\text { Glazebrooket al., 1997; Ball et al., } \\
\text { 2004; Parisyet al., 2007; Mhamdi } \\
\text { et al., } 2010\end{array}$ \\
\hline Alternaria brassicicola & Arabidopsis thaliana & Van Wees et al., 2003 \\
\hline Spodoptera littoralis & Arabidopsis thaliana & Schlaeppi et al., 2008 \\
\hline Pseudomonas syringae & Arabidopsis thaliana & Chaouch et al., 2010 \\
\hline Phytophthora brassicae & Arabidopsis thaliana & $\begin{array}{l}\text { Roetschi et al., 2001; Maughan et al., } \\
2010\end{array}$ \\
\hline RNA viruses & Arabidopsis thaliana & Wang et al., 2011 \\
\hline Pseudomonas syringae & Nicotiana tabacum & Ghantaet al., 2011 \\
\hline Meloidogyne incognita & Medicago trunculata & Baldacci-Crespet al., 2012 \\
\hline Phytophthora cinnamomi & Eucalyptus & Dempsey et al., 2012 \\
\hline Botrytis cinerea & Arabidopsis thaliana & Simon et al., 2013 \\
\hline Pseudomonas syringae & Arabidopsis thaliana & Mhamdi et al., 2013 \\
\hline Caterpillar herbivory & Arabidopsis thaliana & Paudel et al., 2013 \\
\hline Botrytis cinerea & Mesembryanthemum crystallinum & Kuźniak et al., 2013 \\
\hline $\begin{array}{l}\text { Colletotrichum gloeosporioides and } \\
\text { Ralstonia solanacearum }\end{array}$ & Arabidopsis thaliana & Hiruma et al., 2013 \\
\hline Alternaria alternata & Mentha arvensis & Sinha et al., 2013 \\
\hline Pseudomonas syringaeand Botrytis cinerea & Nicotiana tabacum & Ghanta et al., 2014 \\
\hline Pseudomonas syringae pv lachrymans & Cucumis sativus & Kuźniak et al., 2014 \\
\hline Magnaporthe oryzae & Oryza sativa & Zhang et al., 2015 \\
\hline Pseudomonas syringae & Arabidopsis thaliana & Datta and Chattopadhyay 2015 \\
\hline Botrytis cinerea & Arabidopsis thaliana & Ferrari et al., 2003; Datta et al., 2015 \\
\hline
\end{tabular}


which is hampered under low GSH conditions (GeuFlores et al., 2011). This explains why the pad2-1 mutant displays constitutive camalexin deficiency and lower glucosinolates induction.

The proteins involved in imparting disease susceptibility of the GSH depleted pad2-1 mutant to $P$. syringae infection has been reported recently. It has been identified that the mutant actually fails to efficiently regulate several proteins involved in the PTI-related first line of defence as well as ETI-related R-gene products, thus signifying the dynamic role of GSH in plant defence (Datta and Chattopadhyay, 2015). These studies cumulatively suggest that the accumulation of GSH is essential for disease resistance. Using high-resolution imaging techniques the temporal and spatial changes of subcellular GSH level during Botrytis cinerea infection in A. thaliana have been shown (Simon et al., 2013). Another recent study demonstrated that increased GSH contributes to stress tolerance and global translational changes in A. thaliana. The translatome analysis also identified several novel genes related to auxin, ABA, and JA biosynthetic pathways as well as signalling genes whose transcription is induced in response to exogenous GSH treatment, which was not reported in any previous transcriptomic data (Cheng et al., 2015). Table 1 summarizes the different host-pathogen systems in which the role of GSH in imparting disease resistance has already been established.

\section{GSH and its Cross-Talk with Phytohormones During Biotic Stress}

Phytohormones are small molecules that are indispensable for the regulation of plant growth, development, reproduction, and survival. Diverse small-molecule phytohormones viz., SA, JA, ET, abscisic acid (ABA) and brassinosteroids play pivotal roles in regulating the plant defence signalling network (Dong, 1998; Dahl and Baldwin, 2007; Grant and Lamb, 2006; Howe and Jander, 2008; Loake and Grant, 2007; Pieterse et al., 2009; van Wees et al., 2003; van Loon et al., 2006; Vlot et al., 2008;). Extensive synergistic and/or antagonistic crosscommunications among their signalling pathways enables the plant to finely regulate its immune response (Bostock, 2005; Kunkel and Brooks, 2002; Pieterse et al., 2009; Reymond and Farmer, 1998). Although the detailed mechanisms of these cross-talks are not fully described as yet, accumulating evidence points to imperative roles for GSH in phytohormone signalling during biotic stress (Ghanta et al., 2014; Mhamdi et al., 2013; Spoel and Loake, 2011). The different milestones attained in exploring the role of GSH-phytohormone cross-talk in plant defence signalling network has been summarized in Table 2 .

\section{GSH-SA Interplay}

Plants synthesize SA in response to invasion by a diverse range of phytopathogens and it plays an essential role in establishing both local and systemic acquired resistance (SAR) (Loake and Grant, 2007). SA signalling is mediated by at least two mechanisms, the NPR1 dependent and the NPR1 independent pathways (Blanco et al., 2009). Under normal condition, NPR1 exists as an oligomer. SA induces a change in the cellular redox potential, which leads to the reduction of NPR1 oligomer to its active monomeric form. It has been reported that the oligomerization of NPR1 is facilitated by its Snitrosylation at cysteine-156 residue by Snitrosoglutathione (GSNO). Conversely, the SAinduced monomerization of the NPR1 oligomer is catalyzed by thioredoxins (TRXs) through reduction or oxidation of its intermolecular disulphide bonds (Tada et al., 2008). Monomeric NPR1 is then translocated from the cytosol into the nucleus where it acts as a transcriptional co-activator of several SAresponsive genes (Després et al., 2003; Mou et al., 2003). NPR1 is also a key molecule in modulating the SA-JA cross-talk during stress. In the cytosol, monomeric NPR1 negatively regulates JA-responsive gene expression, perhaps by inhibiting positive regulators of JA-responsive genes or by enabling the delivery of negative regulators of JA-responsive genes to the nucleus (Spoel et al., 2003).

Fascinatingly, the interplay of SA with ROS and GSH under various stress conditions has been supported by different lines of evidence (HerreraVásquez et al., 2015). One of the earliest reports suggesting GSH-SA interplay comes from a study on pea seedlings. In pea seedlings, a rise in the reduced GSH content and fall in the oxidized glutathione (GSSG) level, together with an increased GSH:GSSG ratio has been observed in response to exogenous SA treatment which signifies a modulation of GSH metabolism by SA (Srivastava and Dwivedi, 1998). 
Table 2: Different milestones attained in exploring the role GSH-phytohormone cross-talk in plant defence signalling network

\begin{tabular}{|c|c|c|}
\hline Milestones & Host system & References \\
\hline \multicolumn{3}{|c|}{ GSH-SA interplay } \\
\hline Exogenous SA treatment leads to an increase in GSH & Pea seedlings & (Srivastava and Dwivedi 1998) \\
\hline $\begin{array}{l}\text { SA induces GST transcription during plant defence via an ocs } \\
\text { enhancer element in the GST promoter region }\end{array}$ & Arabidopsis & (Chen and Singh 1999) \\
\hline $\begin{array}{l}\text { Thermo-tolerance as a consequence of SA treatment coincides } \\
\text { with an increase in GSH level but GSH:GSSG ratio remains unaltered }\end{array}$ & Tobacco & (Dat et al., 2000) \\
\hline $\begin{array}{l}\text { INA (SA analogue) treatment increases the GSH level leading to a } \\
\text { reduction of NPR1 and subsequent PR1 gene expression }\end{array}$ & Arabidopsis & (Mou et al., 2003) \\
\hline $\begin{array}{l}\text { Exogenous treatments with SA, INA as well as pathogen infection } \\
\text { increases GSH content and GSH: GSSG ratio }\end{array}$ & $\begin{array}{l}\text { Arabidopsis; Tobacco-TMV } \\
\text { infection }\end{array}$ & $\begin{array}{l}\text { (Fodor et al., 1997; } \\
\text { Vanacker et al., 2001; Mateo et } \\
\text { al., 2006) }\end{array}$ \\
\hline $\begin{array}{l}\text { Constitutive overexpression of SA induces GSH-mediated nickel } \\
\text { tolerance }\end{array}$ & Thlaspi sp. & (Freeman et al., 2005) \\
\hline $\begin{array}{l}\text { Protection of ozone-induced leaf injury by SA coincides with an } \\
\text { increase in de novo GSH synthesis }\end{array}$ & Arabidopsis & (Yoshida et al., 2009) \\
\hline $\begin{array}{l}\text { GR1-dependent GSH statusplays a crucial role in leaf responses to } \\
\text { intracellular } \mathrm{H}_{2} \mathrm{O}_{2} \text { including accumulation of SA, induction of PR } \\
\text { genes and SA signalling pathway }\end{array}$ & Arabidopsis & (Mhamdi et al., 2010) \\
\hline $\begin{array}{l}\text { Higher GSH level observed in SA-deficient plants during RNA } \\
\text { virus infection }\end{array}$ & Arabidopsis-CMV & (Wang et al., 2011) \\
\hline GSH regulates the SA-mediated suppression of JA signalling & $\begin{array}{l}\text { Arabidopsis-Alternaria } \\
\text { brassicicola/Botrytis cinerea }\end{array}$ & (Koornneef et al., 2008) \\
\hline JA treatment decreases GSH level & Arabidopsis & (Spoel and Loake 2011) \\
\hline $\begin{array}{l}\text { Simultaneous SA and JA application increase GSH level suggesting } \\
\text { a prioritization of the SA pathway }\end{array}$ & Arabidopsis & (Koornneef et al., 2008) \\
\hline $\begin{array}{l}\text { GSH signaling acts through NPR1-dependent SA-mediated pathway } \\
\text { to mitigate biotic stress }\end{array}$ & Tobacco & (Ghanta et al., 2011b) \\
\hline $\begin{array}{l}\mathrm{GSH} \text { regulates SA accumulation at the level of ICS1 expression and } \\
\text { GSH also act independently of NPR1 to allow increased intracellular } \\
\mathrm{H}_{2} \mathrm{O}_{2} \text { to activate SA signalling }\end{array}$ & Arabidopsis & (Han et al., 2013a) \\
\hline \multicolumn{3}{|l|}{ GSH-ET interplay } \\
\hline An ET-responsive GST gene cluster was characterised in carnation & Carnation & (Itzhaki and Woodson 1993) \\
\hline $\begin{array}{l}\text { ET synthesis is hampered when the GSH pool shifts towards } \\
\text { oxidized state by exogenous GSSG treatment }\end{array}$ & White spruce & (Belmonte et al., 2005) \\
\hline $\begin{array}{l}\text { ACO transcripts increased in spruce somatic embryos grown in } \\
\text { excess GSH condition }\end{array}$ & White spruce & (Stasolla et al., 2004) \\
\hline $\begin{array}{l}\text { S-adenosylmethionine synthase transcript decreases in Brassica } \\
\text { napus grown in excess GSSG condition }\end{array}$ & Brassica & (Stasolla et al., 2008) \\
\hline $\begin{array}{l}\text { ET biosynthesis is assumed to be controlled by GSH via } \\
\text { transcriptional regulation of ACO and S-adenosylmethionine synthase }\end{array}$ & Brassica; Spruce & (Stasolla 2010) \\
\hline $\begin{array}{l}\text { ET controls GSH biosynthesis positively in ozone exposed } \\
\text { A. thaliana leaves }\end{array}$ & Arabidopsis & (Yoshida et al., 2009) \\
\hline $\begin{array}{l}\text { GSH-dependent lead resistance was impaired in ET signalling } \\
\text { mutant, ein2-1 }\end{array}$ & Arabidopsis & (Cao et al., 2009) \\
\hline Multistep involvement of GSH with SA and ET to combat stress & Tobacco-Alternaria alternata & (Ghanta et al., 2014) \\
\hline $\begin{array}{l}\text { GSH induces ET biosynthesis by modulating the transcriptional and } \\
\text { post-transcriptional regulations of its key enzymes, ACS and ACO }\end{array}$ & $\begin{array}{l}\text { Arabidopsis-Botrytis } \\
\text { cinerea/salt stress }\end{array}$ & (Datta et al., 2015) \\
\hline
\end{tabular}




\section{GSH-JA interplay}

JA treatment increases GSH synthesis but did not alter the GS
content in unstressed plants
JA increases GSH metabolism under water stress
Intracellular GSH is involved in methyl MeJA signalling
GSNOR mediates JA and ET biosynthesis and JA-elicited
responses in in response to insect feeding
MeJA treatment induces GPX expression
Increased GSH confers tolerance to drought and salt stress by
enhancing global translation of JA-responsive genes
GSH modulates the antagonistic interaction between SA and
JA pathways at the level of NPR1

\section{GSH-ABA Interplay}

In two maize genotypes differing in stress tolerance, $\mathrm{ABA}$ differentially affected the GSH content, GSH:GSSG ratio, GR activity, and g-ECS transcript level

GSH content did not vary in potato tubers treated with ABA GSH-ABA interplay provides stress tolerance against abiotic stress factors

\section{GSH-SA interplay}

\section{Potato \\ Arabidopsis; Wheat}

(Xiang and Oliver 1998)

(Shan and Liang 2010)

(Akter et al., 2010)

(Wünsche et al., 2011)

(Saisavoey et al., 2014)

(Cheng et al., 2015)

(Spoel et al., 2003; Koornneef et al., 2008)

(Kellos et al., 2008)

(Stroinski et al., 2010)

(Chen et al., 2012; Wei et al., 2015)

Exogenous SA treatment leads to an increase in GSH

Pea seedlings

(Srivastava and Dwivedi 1998)

Subsequently, SA and $\mathrm{H}_{2} \mathrm{O}_{2}$ were shown to induce GST transcription during plant defence via an ocs element which is an enhancer element present in the GST promoter region (Chen and Singh,1999). In another study, thermo-tolerance as a consequence of SA treatment was shown to coincide with an increase in both GSH and GSSG levels in shoot while the GSH redox ratio remained unaltered (Dat et al., 2000).

A treatment with 2, 6-dichloroisonicotinic acid (INA), the biologically active analogue of SA, augmented the GSH level in cells leading to the reduction of NPR1 and subsequent expression of the PR1 gene (Mou et al., 2003). Similarly, exogenous treatments with SA, INA as well as pathogen infection have been reported to increase GSH content and GSH: GSSG ratio in plants (Fodor et al., 1997; Mateo et al., 2006; Vanacker et al., 2001). In several reports, changes in GSH levels were reported to occur during salinity as well as osmotic stresses (Borsani et al., 2001). In another study, GSH-mediated nickel tolerance was shown be induced due to constitutive overexpression of SA in Thlaspi hyper accumulators (Freeman et al., 2005). Protection of ozone-induced leaf injury in $A$. thaliana by SA coincided with an increase in the de novo synthesis of GSH (Yoshida et al., 2009). In fact, ozone exposure leads to ROS generation and subsequent cell death. SA and ET production is induced under such condition to decrease the magnitude of ozone-induced cell death via induction of GSH biosynthesis. It has been reported that unlike the wild-type, mutants deficient in ET signalling (ein2) or SA biosynthesis (sid2) generated high levels of superoxide, lower levels of GSH and exhibited visible leaf injury. The activities of the GSH biosynthetic enzymes were also affected in these mutants. Furthermore, ozone-induced leaf damage detected in ein 2 and sid 2 was alleviated by exogenous GSH treatment. GSH status has been demonstrated to regulate SA and other biotic stress response pathways in A. thaliana. It has been demonstrated that the GR1-dependent GSH statusplays a crucial role in modulating multiple leaf responses to intracellular $\mathrm{H}_{2} \mathrm{O}_{2}$ including limitation of lesion formation, SA accumulation, induction of PR genes and signalling through SA and JA pathways (Mhamdi et al., 2010). In another report, the role of GSH against RNA viruses in SA-deficient plants has been described. The levels of virus replication were found to be higher in the SA-deficient plants during the first 10 days, but lower than the wild-type seedlings 20 
days after infection. It has been demonstrated that the higher level of GSH and ascorbic acid observed in SA-deficient plants perhaps contribute to their alleviated symptoms (Wang et al., 2011).

GSH has also been shown to interfere with SAmediated suppression of JA signalling in plants. The boost in GSH levels after SA treatment was shown to coincide accurately with the window of opportunity in which SA could suppress JA-induced PDF1.2 expression. Inhibition of GSH biosynthesis by l-buthioninesulfoximine (BSO) strongly reduced this suppression of the JA-responsive PDF1.2 gene by SA (Koornneef and Pieterse, 2008). Interestingly, JA can also influence the redox state of cells by decreasing the total amount of GSH and this shifts the GSH: GSSG ratio towards the oxidized state (Spoel and Loake, 2011). However, on simultaneous application of SA and JA, an increase in the GSH level was observed suggesting a prioritization of the SA pathway over the JA pathway (Koornneef et al., 2008). Nonetheless, the mechanism of how does the SA-mediated cellular reduction modulates JAinducible responses still remains obscure.

To obtain deeper insight into the mechanism how the GSH-SA interplay is involved in mitigating biotic stress, Ghanta et al. (2011b) used transgenic tobacco plants with enhanced GSH content and exhibiting resistance to pathogenesis as well. It was observed that the expression levels of NPR1 and NPR1dependent genes like $P R 1$, mitogen-activated protein kinase kinase, glutamine synthetase, etc. were significantly enhanced in the transgenic plants as compared to the wild-type. Conversely, no significant alteration in the expression levels of NPR1independent genes like $P R 2, P R 5$, and short-chain dehydrogenase/reductase family protein was observed. These observations suggested that GSH activates SA-mediated defence, presumably through the NPR1-dependent pathway (Ghanta et al., 2011b; Ghanta and Chattopadhyay, 2011). In a subsequent study, the transgenic tobacco plants with enhanced GSH levels were reported to synthesize more SA than the wild-type plants (Ghanta et al., 2011a). Activation of SA related genes and enhanced resistance to pathogenesis under augmented GSH condition was also observed in later studies (Ghanta et al., 2014).

It has subsequently been reported that GSH regulates SA accumulation at the level of isochorismate synthetase 1 (ICS1) expression and that an increase in the intracellular $\mathrm{H}_{2} \mathrm{O}_{2}$ level can function to activate the SA signalling (Han et al., 2013a). The $\mathrm{H}_{2} \mathrm{O}_{2}$-triggered changes in GSH status have been suggested not merely to be a passive response to oxidative stress. In fact, this modulation of GSH status links the elevated intracellular $\mathrm{H}_{2} \mathrm{O}_{2}$ production to activation of the ICS1-dependent SA pathway. The accumulated SA then leads to activation of NPR1 function through reductive processes, to which GSH also contributes. This general model has been depicted in Fig. 1.

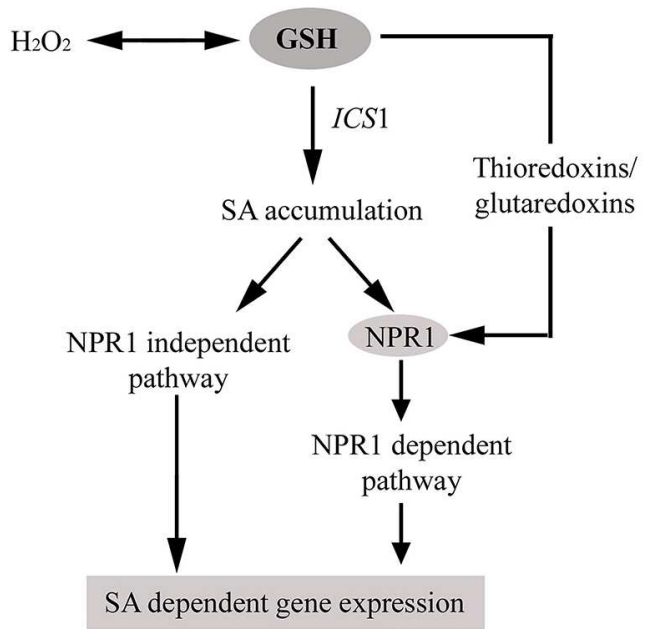

Fig. 1: GSH induces SA signalling via NPR1 dependent and NPR1 independent pathways in plants. GSH on one hand directly induces NPR1 dependent pathway presumably through thioredoxins and glutaredoxins. On the other hand, oxidation by $\mathrm{H}_{2} \mathrm{O}_{2}$ modulates GSH status. This oxidative modulation is a part of the signal network required for optimal ICS1 dependent SA accumulation that then leads to activation of NPR1 dependent as well as independent pathways

\section{GSH-ET Interplay}

ET, a gaseous phytohormone, is known to play significant roles in plant defence and participate in cross-talk with other signalling molecules. ET and JA have been widely reported to act synergistically against necrotrophic pathogens (Penninckx et al., 1998). In some cases however, a synergistic interaction between ET and SA has also been demonstrated to induce SAR and SA-mediated gene expression in plants (Lawton et al., 1994; Verberne et al., 2003; Vos et al., 2006). 
Reports demonstrating GSH-ET interplay dates back to the early 1990s when an ET-responsive GST gene cluster was characterized in carnation (Itzhaki and Woodson, 1993). In another report, ET synthesis was observed to be hampered in spruce somatic embryo when the GSH pool was shifted towards oxidized state by exogenous GSSG treatment (Belmonte et al., 2005). Molecular studies revealed that ACC oxidase (ACO) transcripts increased in spruce somatic embryos grown in excess GSH (reduced) condition (Stasolla et al., 2004). In a subsequent study, transcripts of S-adenosylmethionine synthase was found to be decreased in Brassica napus when grown in excess GSSG (oxidized) condition (Stasolla et al., 2008). Hence, the biosynthesis of ET has been assumed to be controlled by GSH via transcriptional regulation of the two biosynthetic enzymes: S-adenosylmethionine synthase and ACO (Stasolla, 2010).

ET has also been reported to control GSH biosynthesis positively in ozone exposed $A$. thaliana leaves (Yoshida et al., 2009). Again, the ein2-1 mutant with impaired ET signalling has been shown to exhibit impaired GSH-dependent lead resistance, which was related to constitutive repression of $\gamma-E C S$ gene and consequently reduced GSH content (Cao et al., 2009). In transgenic tobacco with enhanced GSH content, up-regulation of ET related transcripts like $A C O, E R F 4$ and $W R K Y 1$ and up-accumulation of proteins like ACC synthase (ACS) and ACO has been reported recently (Ghanta et al., 2014). These transgenic plants have also been reported to exhibit tolerance against pathogenesis as well as osmotic stress thus demonstrating the involvement of GSHET interplay in imparting stress tolerance in plants (Ghanta et al., 2014; Kumar et al., 2014).

The molecular mechanism of the GSH-ET crosstalk during necrotrophic infection as well as abiotic stress has been solved only very recently. It has been demonstrated that GSH induces ET biosynthesis by modulating the transcriptional and post-transcriptional regulations of its key enzymes, ACS and ACO in $A$. thaliana (Datta et al., 2015). Transgenic plants with enhanced GSH content were found exhibit upregulation of $A C S 2, A C S 6$, and $A C O 1$ at transcript as well as protein levels while down-regulation was observed in the GSH depleted pad2-1 mutant. Furthermore, GSH was shown to induce $A C S 2$ and
ACS6 transcription in a WRKY33 dependent manner. For $A C O 1$, however, GSH increased the stability of $A C O 1 \mathrm{mRNA}$ without affecting its promoter activity. In addition, the $\mathrm{ACO} 1$ protein can be a subject for $\mathrm{S}$ glutathionylation while S-glutathionylation of ACS2 and ACS6 proteins was not detected. Thus, a dual-level regulation of ET biosynthesis by GSH during stress has been proposed (Fig. 2; Datta et al., 2015).

\section{GSH- JA Interplay}

The role of JA in plant defence has long been reported (Farmer and Ryan, 1992; Gundlach et al., 1992; Turner et al., 2002). JA-dependent signalling has been reported to play a crucial role in pathogen attack, especially necrotrophs, wounding and insect feeding (Glazebrook, 2005; Thomma et al., 2001). JA has been known to function antagonistically with SA in defence signalling. JA treatment has been shown to increase the mRNA levels and the capacity for GSH synthesis but it did not alter the GSH content in unstressed plants (Xiang and Oliver, 1998). In a later study, it was observed that JA leads to an increase in GSH metabolism under water stress in Agropyron cristatum (Shan and Liang, 2010). Involvement of intracellular GSH has also been studied in methyl jasmonate (MeJA) signalling (Akteret al., 2010). Again, S-Nitrosoglutathione reductase (GSNOR) has been shown to mediate JA and ET biosynthesis in Nicotiana attenuata in response to insect feeding (Wünsche et al., 2011). MeJA treatment has also been reported to induce expression of GPX in Pueraria mirifica (Saisavoey et al., 2014). It has recently been demonstrated that increased GSH confers tolerance to drought and salt stress in Arabidopsis by enhancing global translation of JA-responsive genes (Cheng et al., 2015). GSH has also been implicated in the antagonistic interaction between SA and JA pathways at the level of NPR1 as discussed earlier (Koornneef et al., 2008; Spoel et al., 2003).

Two possibilities could explain the dual effect of GSH on signalling through the SA and JA pathways in response to stress (Han et al., 2013b). First, GSH status can act to modulate a master switch that regulates the oxidative activation of both pathways. A second scenario would involve regulation of both pathways in parallel. Whatever may be the case, the SA- JA interplay mediated by other redox-linked factors could act downstream to determine the relative 

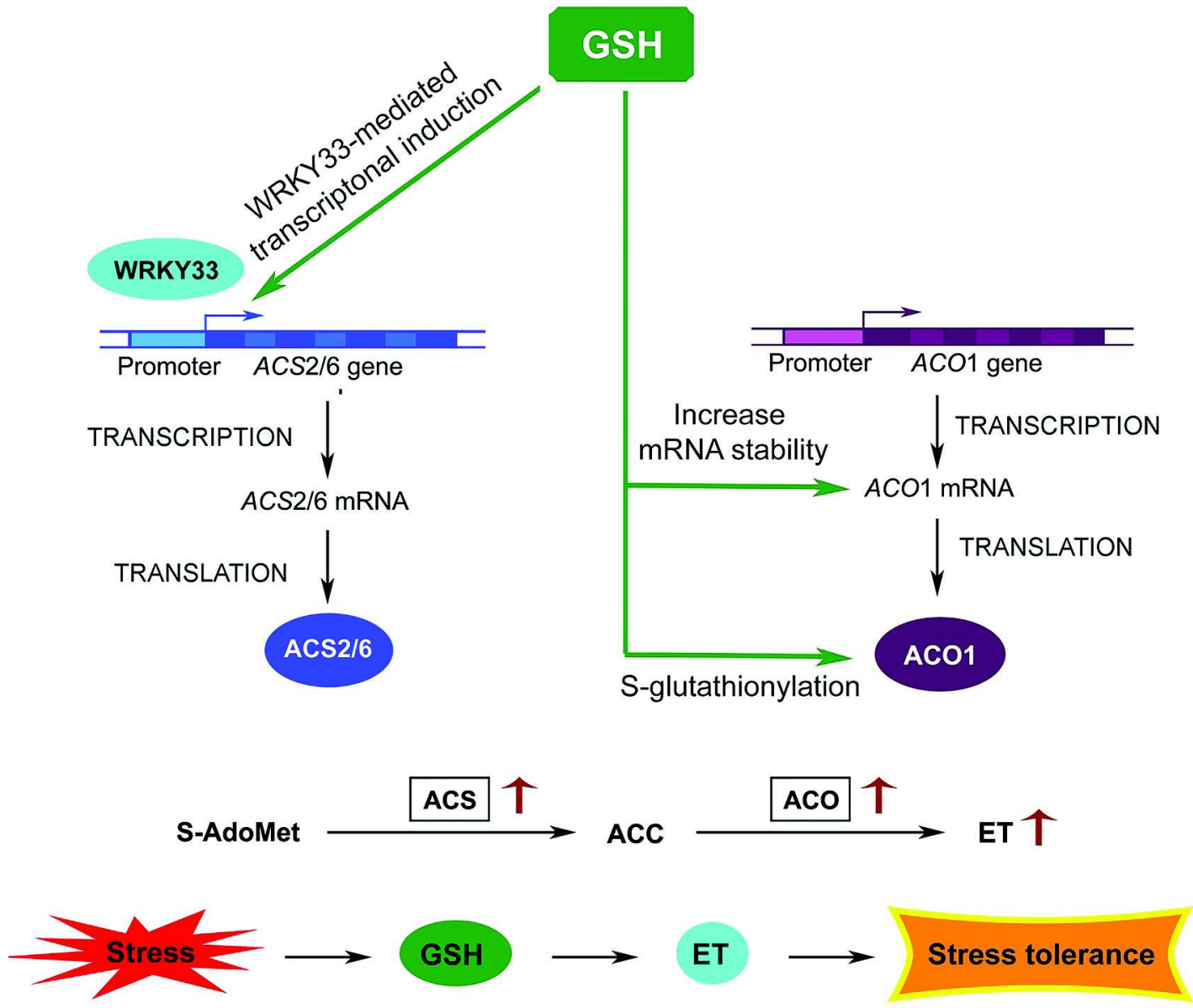

Fig. 2: Stress conditions lead to an increase in cellular GSH level in plants. Increased GSH then induces $A C S 2$ and $A C S 6$ transcription in a WRKY33 dependent manner during stress. This increases the transcript levels of $A C S 2$ and $A C S 6$. Consequently, more ACS2 and ACS6 proteins are synthesized. On the other hand, GSH enhances the ACO1 mRNA stability and consequently more ACO1 protein is synthesized. Also, ACO1 protein is S-glutathionylationed. Together, this leads to increased synthesis of ET. Increased ET level then switches on the ET signalling pathway and increases stress tolerance in plants. Figure adapted and modified from Datta et al. 2015

dominance of these two key defence signalling pathways.

\section{GSH-ABA Interplay}

Apart from these three phytohormones, ABA also plays a significant role in environmental stress tolerance. ABA cross-communicates with the SAJA-ET network by antagonizing the onset of SAdependent defences and SAR (Mohr and Cahill, 2007; Yasuda et al., 2008). Moreover, ABA attenuates the JA/ET-dependent gene expression (Anderson et al., 2004) and affects JA biosynthesis and resistance against JA-inducing necrotrophic pathogens (Adie $e t$ al., 2007; Flors et al., 2008). Interplay between ABA and GSH has also been reported. ABA has been demonstrated to differentially regulate the GSH content, GSH:GSSG ratio, $\gamma-E C S$ transcript level and GR activity in two maize genotypes which varies in their stress tolerance potentials (Kellos et al., 2008). However, it was subsequently reported that ABA treatment did not alter the GSH levels in potato tubers (Stroiñski et al., 2010). In several other studies, GSHABA interplay has been reported in providing stress tolerance against abiotic stress factors (Chen et al., 2012; Wei et al., 2015). But whether this interplay is also involved in imparting biotic stress tolerance remains to be studied in future. 


\section{Conclusion and Future Perspective}

Dissecting the signalling network that operates during disease development in plants has revealed the association of various stress-related phytohormones along with several other signal molecules. GSH is mainly associated with the activation and modulation of different phytohormones and subsequent regulation of a various resistance genes. Most of the studies were focused on the cross-talk of GSH with SA, ET, and JA signalling pathways during stress. In SA and JA signalling pathways, GSH serves as an important intermediate to modulate their signalling cascades through NPR1 during specific stress responses. Again, in some cases, JA elicitation under stress condition

\section{References}

Adie B A T, Pérez-Pérez J, Pérez-Pérez M M, Godoy M, Sánchez-Serrano J-J, Schmelz E A and Solano R (2007) $\mathrm{ABA}$ is an essential signal for plant resistance to pathogens affecting JA biosynthesis and the activation of defenses in Arabidopsis Plant Cell 19 1665-1681 https://www.ncbi. nlm.nih.gov/pmc/articles/PMC1913739/

Akter N, Sobahan M A, Hossain M A, Uraji M, Nakamura Y, Mori I C and Murata Y (2010) The involvement of intracellular glutathione in methyl jasmonate signaling in Arabidopsis guard cells Biosci Biotechnol Biochem 742504 2506 https://www.jstage.jst.go.jp/article/bbb/74/12/ 74_100513/_pdf

Anderson J P, Badruzsaufari E, Schenk P M, Manners J M, Desmond O J, Ehlert C, Maclean D J, Ebert P R and Kazan K (2004) Antagonistic interaction between abscisic acid and jasmonate-ethylene signaling pathways modulates defense gene expression and disease resistance in Arabidopsis Plant Cell 16 3460-3479 http:// www.plantcell.org/content/16/12/3460

Baldacci-Cresp F, Chang C, Maucourt M, Deborde C, Hopkins J, Lecomte P, Bernillon S, Brouquisse R, Moing A, Abad P, Herouart D, Puppo A, Favery B and Frendo P (2012) (Homo)glutathione deûciency impairs root-knot nematode development in Medicago truncatula PLoS Pathog 8 e1002471 http://journals.plos.org/plospathogens/ article?id=10.1371/journal.ppat.1002471

Ball L, Accotto G-P, Bechtold U, Creissen G, Funck D, Jimenez A, Kular B, Leyland N, Mejia-Carranza J, Reynolds H, can also induce GSH biosynthesis in plants. On the other hand, GSH enhances ET biosynthesis by a twostep process in response to necrotrophic infection as well as abiotic stress. Identification of the GSHmediated induction of the ABA signalling pathway can provide a distinct linkage between biotic and abiotic stress responses as well. It can also add a more elaborate view of the interrelationship among various stress hormones during disease resistance in plants. However, the molecular mechanisms of the GSH-JA and GSH-ABA cross-talks during various stress responses are still unsolved. Whether GSH can induce the signalling cascade of these phytohormones or their biosynthesis pathways during stress needs to be investigated in future.

Karpinski S and Mullineaux P M (2004) Evidence for a direct link between glutathione biosynthesis and stress defense gene expression in Arabidopsis Plant Cell 16 24482462 https://www.ncbi.nlm.nih.gov/pmc/articles/ PMC520945/

Belmonte M F, Donald G, Reid D M, Yeung E C and Stasolla C (2005) Alterations of the glutathione redox state improve apical meristem structure and somatic embryo quality in white spruce (Picea glauca) J Exp Bot 56 2355-2364 https:/ /academic.oup.com/jxb/article-lookup/doi/10.1093/jxb/ eri228

Blanco F, Salinas P, Cecchini NM, Jordana X, Van Hummelen P, Alvarez M E and Holuigue L (2009) Early genomic responses to salicylic acid in Arabidopsis Plant Mol Biol 70 79-102 https://link.springer.com/article/10.1007/ s11103-009-9458-1

Bolter C, Brammall R A, Cohen R and Lazarovits G (1993) Glutathione alterations in melon and tomato roots following treatment with chemicals which induce disease resistance to Fusarium wilt Physiol Mol Plant Pathol 42 321-336 http://www.sciencedirect.com/science/article/pii/ S0885576505800098

Borsani O, Valpuesta V and Botella M A (2001) Evidence for a role of salicylic acid in the oxidative damage generated by $\mathrm{NaCl}$ and osmotic stress in Arabidopsis seedlings Plant Physiol 126 1024-1030 https://www.ncbi.nlm.nih.gov/pmc/ articles/PMC116459/

Bostock R M (2005) Signal crosstalk and induced resistance: straddling the line between cost and benefit Annu Rev 
Phytopathol 43 545-580 http://www.annualreviews.org/ doi/full/10.1146/annurev.phyto.41.052002.095505? url_ver=Z39.88-2003\&rfr_id=ori\%3Arid\%3Acrossref.org \&rfr_dat $=$ cr_pub\%3Dpubmed\&

Böttcher C, Westphal L, Schmotz C, Prade E, Scheel D and Glawischnig E (2009) The multifunctional enzyme CYP71B15 (PHYTOALEXIN DEFICIENT3) converts cysteine-indole-3-acetonitrile to camalexin in the indole3-acetonitrile metabolic network of Arabidopsis thaliana Plant Cell 21 1830-1845 https://www.ncbi.nlm.nih.gov/ pmc/articles/PMC2714930/

Cao S, Chen Z, Liu G, Jiang L, Yuan H, Ren G, Bian X, Jian H and Ma X (2009) The ArabidopsisEthylene-Insensitive 2 gene is required for lead resistance Plant physiolbiochem $\mathbf{4 7}$ 308-312 http://www.sciencedirect.com/science/article/pii/ S0981942808002490?via\%3Dihub

Chamnongpol S, Willekens H, Moeder W, Langebartels C, Sandermann H, Van Montagu M, Inzé D and Van Camp W (1998) Defense activation and enhanced pathogen tolerance induced by $\mathrm{H}_{2} \mathrm{O}_{2}$ in transgenic tobacco Proc Nat Acad Sci USA 95 5818-5823 https://www.ncbi.nlm.nih.gov/pmc/ articles/PMC20463/

Chaouch S, Queval G, Vanderauwera S, Mhamdi A, Vandorpe M, Langlois-Meurinne M, Van Breusegem F, Saindrenan P and Noctor G (2010) Peroxisomal hydrogen peroxide is coupled to biotic defense responses by ISOCHORISMATE SYNTHASE1 in a daylength-related manner Plant Physiol 153 1692-1705 https://www.ncbi.nlm.nih.gov/pmc/articles/ PMC2923881/

Chen J-H, Jiang H-W, Hsieh E-J, Chen H-Y, Chien C-T, Hsieh HL and Lin T-P (2012) Drought and salt stress tolerance of an Arabidopsis glutathione S-transferase U17 knockout mutant are attributed to the combined effect of glutathione and abscisic acid Plant Physiol 158 340-351 https:// www.ncbi.nlm.nih.gov/pmc/articles/PMC3252094/

Chen W and Singh K B (1999) The auxin, hydrogen peroxide and salicylic acid induced expression of the Arabidopsis GST6 promoter is mediated in part by an ocs element Plant $J 19$ 667-677 http://onlinelibrary.wiley.com/doi/10.1046/j.1365313x.1999.00560.x/abstract;jsessionid=BA1F7DCBEFD 528696997708EF56BD905.f04t03

Cheng M-C, Ko K, Chang W-L, Kuo W-C, Chen G-H and Lin T$P$ (2015) Increased glutathione contributes to stress tolerance and global translational changes in Arabidopsis Plant J 83 926-939 http://onlinelibrary.wiley.com/doi/ 10.1111/tpj.12940/abstract

Creissen G, Firmin J, Fryer M, Kular B, Leyland N, Reynolds H, Pastori G, Wellburn F, Baker N, Wellburn A and
Mullineaux P (1999) Elevated glutathione biosynthetic capacity in the chloroplasts of transgenic tobacco plants paradoxically causes increased oxidative stress Plant Cell 11 1277-1292 http://www.plantcell.org/content/11/7/1277

Dahl C C von and Baldwin I T (2007) Deciphering the role of ethylene in plant-herbivore interactions J Plant Growth Regul 26 201-209 https://link.springer.com/article/10.1007/ s00344-007-0014-4

Dat J F, Lopez-Delgado H, Foyer C H and Scott I M (2000) Effects of salicylic acid on oxidative stress and thermotolerance in tobacco J Plant Physiol 156 659-665 http://www.sciencedirect.com/science/article/pii/ S017616170080228X

Datta R and Chattopadhyay S (2015) Changes in the proteome of pad2-1, a glutathione depleted Arabidopsis mutant, during Pseudomonas syringae infection J Prot 126 82-93 http://www.sciencedirect.com/science/article/pii/ S1874391915002572

Datta R, Kumar D, Sultana A, Hazra S, Bhattacharyya D and Chattopadhyay S (2015) Glutathione regulates 1aminocyclopropane-1-carboxylate synthase transcription via WRKY33 and 1-aminocyclopropane-1-carboxylate oxidase by modulating messenger RNA stability to induce ethylene synthesis during stress Plant Physiol 169 29632981 https://www.ncbi.nlm.nih.gov/pmc/articles/ PMC4677924/

Dempsey R W, Merchant A and Tausz M (2012) Differences in ascorbate and glutathione levels as indicators of resistance and susceptibility in Eucalyptus trees infected with Phytophthora cinnamomi Tree Physiol 32 1148-1160 https:/academic.oup.com/treephys/article/32/9/1148/ 1652739/Differences-in-ascorbate-and-glutathione-levelsas

Després C, Chubak C, Rochon A, Clark R, Bethune T, Desveaux D and Fobert P R (2003) The Arabidopsis NPR1 disease resistance protein is a novel cofactor that confers redox regulation of DNA binding activity to the basic domain/ leucine zipper transcription factor TGA1 Plant Cell 15 2181-2191 https://www.ncbi.nlm.nih.gov/pmc/articles/ PMC181339/

Dong X (1998) SA, JA, ethylene, and disease resistance in plants Curr Opin Plant Biol $1316-323$ http://www.sciencedirect. com/science/article/pii/1369526688800530?via\%3Dihub

Dron M, Clouse S D, Dixon R A, Lawton M A and Lamb C J (1988) Glutathione and fungal elicitor regulation of a plant defense gene promoter in electroporated protoplasts Proc Nat Acad Sci USA 85 6738-6742 http://www.pnas.org/ content/85/18/6738.full.pdf 
Dubreuil-Maurizi C and Poinssot B (2012) Role of glutathione in plant signaling under biotic stress Plant Signal Behav 7 210-212 https://www.ncbi.nlm.nih.gov/pmc/articles/ PMC3405692/

El-Zahaby H M (1995) Effects of powdery mildew infection of barley on the ascorbate-glutathione cycle and other antioxidants in different host-pathogen interactions Phytopathol 851225 http://www.refdoc.fr/Detailnotice? cpsidt $=3698412$

Farmer E E and Ryan C A (1992) Octadecanoid precursors of jasmonic acid activate the synthesis of wound-inducible proteinase inhibitors Plant Cell 4 129-134 http:// www.plantcell.org/content/4/2/129

Ferrari S, Plotnikova J M, De Lorenzo G and Ausubel F M (2003) Arabidopsis local resistance to Botrytis cinerea involves salicylic acid and camalexin and requires EDS4 and PAD2, but not SID2, EDS5 or PAD4 Plant J 35 193$205 \mathrm{http} / /$ onlinelibrary.wiley.com/doi/10.1046/j.1365313X.2003.01794.X/full

Flors V, Ton J, van Doorn R, Jakab G, García-Agustín P and Mauch-Mani B (2008) Interplay between JA, SA and ABA signalling during basal and induced resistance against Pseudomonas syringae and Alternaria brassicicola Plant $J \quad 54 \quad 81-92$ http://dx.doi.org/10.1111/j.1365313X.2007.03397.x

Fodor J, Gullner G, Adam A L, Barna B, Komives T and Kiraly Z (1997) Local and systemic responses of antioxidants to tobacco mosaic virus infection and to salicylic acid in tobacco (role in systemic acquired resistance) Plant Physiol 114 1443-1451 http://www.plantphysiol.org/content/114/ $4 / 1443$

Freeman J L, Garcia D, Kim D, Hopf A and Salt D E (2005) Constitutively elevated salicylic acid signals glutathionemediated nickel tolerance in Thlaspi nickel hyperaccumulators Plant Physiol 137 1082-1091 https:// www.ncbi.nlm.nih.gov/pmc/articles/PMC1065408/

Galant A, Preuss M L, Cameron J C and Jez J M (2011) Plant glutathione biosynthesis: diversity in biochemical regulation and reaction products Front Plant Sci 245 https:// www.ncbi.nlm.nih.gov/pmc/articles/PMC3355797/

Geu-Flores F, Møldrup M E, Böttcher C, Olsen C E, Scheel D and Halkier B A (2011) Cytosolic $\gamma$-glutamyl peptidases process glutathione conjugates in the biosynthesis of glucosinolates and camalexin in Arabidopsis Plant Cell $\mathbf{2 3}$ 2456-2469 https://www.ncbi.nlm.nih.gov/pmc/articles/ PMC3160024/

Geu-Flores F, Nielsen M T, Nafisi M, Møldrup M E, Olsen C E, Motawia M S and Halkier B A (2009) Glucosinolate engineering identifies a gamma-glutamyl peptidase Nat Chem Biol 5 575-577 http://dx.doi.org/10.1038/ nchembio. 185

Ghanta S, Bhattacharyya D and Chattopadhyay S (2011a) Glutathione signaling acts through NPR1-dependent SAmediated pathway to mitigate biotic stress Plant Signal Behav 6 607-609 https://www.ncbi.nlm.nih.gov/pmc/ articles/PMC3142405/

Ghanta S, Bhattacharyya D, Sinha R, Banerjee A and Chattopadhyay S (2011b) Nicotiana tabacum overexpressing $\gamma$-ECS exhibits biotic stress tolerance likely through NPR1-dependentsalicylic acid-mediated pathway Planta 233 895-910 https://link.springer.com/article/ 10.1007/s00425-011-1349-4

Ghanta S and Chattopadhyay S (2011) Glutathione as a signaling molecule: another challenge to pathogens Plant Signal Behav 6 783-788 https://www.ncbi.nlm.nih.gov/pmc/articles/ PMC3218473/

Ghanta S, Datta R, Bhattacharyya D, Sinha R, Kumar D, Hazra S, Mazumdar A B and Chattopadhyay S (2014) Multistep involvement of glutathione with salicylic acid and ethylene to combat environmental stress J Plant Physiol 171 940950 http://www.sciencedirect.com/science/article/pii/ S0176161714000571?via\%3Dihub

Glazebrook J (2005) Contrasting mechanisms of defense against biotrophic and necrotrophic pathogens Annu Rev Phytopathol 43 205-227 http://www.annualreviews.org/ doi/full/10.1146/annurev.phyto.43.040204.135923?url_ ver=Z39.88-2003\&rfr_id=ori\%3Arid\%3Acrossref.org $\& r f r \_$dat $=$cr_pub\%3Dpubmed

Glazebrook J and Ausubel F M (1994) Isolation of phytoalexindeficient mutants of Arabidopsis thaliana and characterization of their interactions with bacterial pathogens Proc Nat Acad Sci USA 91 8955-8959 https:// www.ncbi.nlm.nih.gov/pmc/articles/PMC44725/

Glazebrook J, Zook M, Mert F, Kagan I, Rogers E E, Crute I R, Holub E B, Hammerschmidt R and Ausubel F M (1997) Phytoalexin-deficient mutants of Arabidopsis reveal that $P A D 4$ encodes a regulatory factor and that four $P A D$ genes contribute to downy mildew resistance Genetics 146381 392 https://www.ncbi.nlm.nih.gov/pmc/articles/ PMC1207952/

Gomez L D, Noctor G, Knight M R and Foyer C H (2004) Regulation of calcium signalling and gene expression by glutathione J Exp Bot 55 1851-1859 https:// academic.oup.com/jxb/article-lookup/doi/10.1093/jxb/ erh202

Gönner Mv and Schlösser E (1993) Oxidative stress in interactions 
between Avena sativa L. and Drechslera spp Physiol Mol Plant Pathol 42 221-234

Grant M and Lamb C (2006) Systemic immunity Curr Opin Plant Biol 9 414-420 http://www.sciencedirect.com/science/ article/pii/S1369526606000872?via\%3Dihub

Grill E, Löffler S, Winnacker E L and Zenk M H (1989) Phytochelatins, the heavy-metal-binding peptides of plants, are synthesized from glutathione by a specific gamma-glutamylcysteine dipeptidyl transpeptidase (phytochelatin synthase) Proc Nat Acad Sci USA 866838 6842 https://www.ncbi.nlm.nih.gov/pmc/articles/ PMC297945/

Gullner G, Kömives T and Rennenberg H (2001) Enhanced tolerance of transgenic poplar plants overexpressing gamma-glutamylcysteine synthetase towards chloroacetanilide herbicides J Exp Bot 52 971-979 https:// academic.oup.com/jxb/article/52/358/971/597161/ Enhanced-tolerance-of-transgenic-poplar-plants

Gundlach H, Müller M J, Kutchan T M and Zenk M H (1992) Jasmonic acid is a signal transducer in elicitor-induced plant cell cultures Proc Nat Acad Sci USA 89 2389-2393 https:/ /www.ncbi.nlm.nih.gov/pmc/articles/PMC48663/

Han Y, Chaouch S, Mhamdi A, Queval G, Zechmann B and Noctor G (2013a) Functional analysis of Arabidopsis mutants points to novel roles for glutathione in coupling $\mathrm{H}_{2} \mathrm{O}_{2}$ to activation of salicylic acid accumulation and signaling Antioxid Redox Signal 18 2106-2121 https://www.ncbi.nlm. nih.gov/pmc/articles/pmid/23148658/

Han Y, Mhamdi A, Chaouch S and Noctor G (2013b) Regulation of basal and oxidative stress-triggered jasmonic acid-related gene expression by glutathione Plant Cell Environ 361135 $1146 \mathrm{http} / / /$ onlinelibrary.wiley.com/doi/10.1111/ pce. $12048 /$ full

Herrera-Vásquez A, Salinas P and Holuigue L (2015) Salicylic acid and reactive oxygen species interplay in the transcriptional control of defense genes expression Front Plant Sci 6171 https://www.ncbi.nlm.nih.gov/pmc/articles/ PMC4365548/

Hiruma K, Fukunaga S, Bednarek P, Pislewska-Bednarek M, Watanabe S, Narusaka Y, Shirasu K and Takano Y (2013) Glutathione and tryptophan metabolism are required for Arabidopsis immunity during the hypersensitive response to hemibiotrophs Proc Nat Acad Sci USA 110 9589-9594 https:/www.ncbi.nlm.nih.gov/pmc/articles/PMC3677473/

Howe G A and Jander G (2008) Plant immunity to insect herbivores Annu Rev Plant Biol 59 41-66 http:// www.annualreviews.org/doi/full/10.1146/annurev.arplant. 59.032607.092825?url_ver=Z39.88-2003\&rfr_id=ori\%3
Arid\%3 Acrossref.org\&rfr_dat=cr_pub\%3Dpubmed

Itzhaki H and Woodson W R (1993) Characterization of an ethylene-responsive glutathione S-transferase gene cluster in carnation Plant Mol Biol 22 43-58 https:// www.ncbi.nlm.nih.gov/pubmed/8499618

Jabs T, Dietrich R A and Dangl J L (1996) Initiation of runaway cell death in an Arabidopsis mutant by extracellular superoxide Science 273 1853-1856 http://www.sciencemag. org/cgi/pmidlookup?view=long\& pmid=8791589

Kellos T, Tímár I, Szilágyi V, Szalai G, Galiba G and Kocsy G (2008) Stress hormones and abiotic stresses have different effects on antioxidants in maize lines with different sensitivity Plant Biol (Stuttgart, Germany) 10 563-572 http://onlinelibrary.wiley.com/doi/10.1111/j.14388677.2008.00071.x/pdf

Klessig D F, Durner J, Noad R, Navarre D A, Wendehenne D, Kumar D, Zhou J M, Shah J, Zhang S, Kachroo P, Trifa Y, Pontier D, Lam E and Silva H (2000) Nitric oxide and salicylic acid signaling in plant defense Proc Nat Acad Sci USA 97 8849-8855 http://www.pnas.org/content/97/16/ 8849.abstract

Koornneef A, Leon-Reyes A, Ritsema T, Verhage A, Den Otter F C, Van Loon L C and Pieterse C M J (2008) Kinetics of salicylate-mediated suppression of jasmonate signaling reveal a role for redox modulation Plant Physiol 147 1358$1368 \mathrm{http} / /$ www.plantphysiol.org/content/147/3/1358

Koornneef A and Pieterse C M J (2008) Cross talk in defense signaling Plant Physiol 146 839-844 http:// www.plantphysiol.org/content/146/3/839

Kumar D, Datta R, Sinha R, Ghosh A and Chattopadhyay S (2014) Proteomic profiling of $\gamma$-ECS overexpressed transgenic Nicotiana in response to drought stress Plant Signal Behav 9 e29246 https://www.ncbi.nlm.nih.gov/pmc/ articles/PMC4203497/

Kunert K J and Foyer C H (1993) Thiol/disulfide exchange in plants. In:Sulfur nutrition and assimilation in higher plants. Regulatory, agricultural and environmental aspects. (Eds: De Kok L J, Stulen I, Rennenberg H, Brunold C and Rauser W E)pp 139-151, SPB Academic Publishers

Kunkel B N and Brooks DM(2002) Cross talk between signaling pathways in pathogen defenseCurr Opin Plant Biol5 325331 https://www.ncbi.nlm.nih.gov/pubmed/12179966

Kuzniak E, Glowacki R, Chwatko G, Kopczewski T, Wielanek M, Gajewska E and Sklodowska M (2014) Involvement of ascorbate, glutathione, protein S-thiolation and salicylic acid in benzothiadiazole-inducible defence response of cucumber against Pseudomonas syringae pv lachrymans Physiol Mol Plant Pathol 86 89-97 http://www.refdoc.fr/ 
Detailnotice cpsidt $=28559911$

Kuzniak E, Kazmierczak A, Wielanek M, Glowacki R and Kornas A (2013) Involvement of salicylic acid, glutathione and protein S-thiolation in plant cell death-mediated defence response of Mesembryanthemum crystallinum against Botrytis cinerea Plant physiol biochem 63 30-38 http:// europepmc.org/abstract $/ \mathrm{med} / 23228550$

Lawton K A, Potter S L, Uknes S and Ryals J (1994) Acquired resistance signal transduction in Arabidopsisis ethylene independent Plant Cell 6 581-588 https:// www.ncbi.nlm.nih.gov/pmc/articles/PMC160460/

Levine A, Tenhaken R, Dixon R and Lamb C (1994) $\mathrm{H}_{2} \mathrm{O}_{2}$ from the oxidative burst orchestrates the plant hypersensitive disease resistance response Cell 79 583-593 http:// www.sciencedirect.com/science/article/pii/ 0092867494905444?via\%3Dihub

Loake G and Grant M (2007) Salicylic acid in plant defence - the players and protagonists Curr Opin Plant Biol 10 466$472 \mathrm{http} / /$ www.sciencedirect.com/science/article/pii/ S1369526607001173

van Loon L C, Rep M and Pieterse C M J (2006) Significance of inducible defense-related proteins in infected plants Annu Rev Phytopathol 44 135-162 http://www. annualreviews. org/doi/full/10.1146/annurev.phyto.44.070505. 143425?url_ver=Z39.88-2003\&rfr_id=ori\%3Arid\%3 Acrossref.org\&rfr dat $=$ cr pub\%3Dpubmed

Mateo A, Funck D, Mühlenbock P, Kular B, Mullineaux P M and Karpinski S (2006) Controlled levels of salicylic acid are required for optimal photosynthesis and redox homeostasis J Exp Bot 57 1795-1807 https:// academic.oup.com/jxb/article-lookup/doi/10.1093/jxb/ erj196

Mauch F and Dudler R (1993) Differential induction of distinct glutathione-S-transferases of wheat by xenobiotics and by pathogen attack Plant Physiol 102 1193-1201 http:// www.plantphysiol.org/content/102/4/1193

Maughan S C, Pasternak M, Cairns N, Kiddle G, Brach T, Jarvis R, Haas F, Nieuwland J, Lim B, Müller C, Salcedo-Sora E, Kruse C, Orsel M, Hell R, Miller A J, Bray P, Foyer C H, Murray J A H, Meyer A J and Cobbett C S (2010) Plant homologs of the Plasmodium falciparum chloroquineresistance transporter, PfCRT, are required for glutathione homeostasis and stress responses Proc Nat Acad Sci USA 107 2331-2336 http://www.pnas.org/content/107/5/ 2331.long

May M J, Hammond-Kosack K E and Jones J D G (1996) Involvement of reactive oxygen species, glutathione metabolism, and lipid peroxidation in the Cf-gene- dependent defense response of tomato cotyledons induced by race-specific elicitors of Cladosporium fulvum Plant Physiol 110 1367-1379 https://www.ncbi.nlm.nih.gov/pmc/ articles/PMC160932/

May M J, Vernoux T, Leaver C, Montagu M V and Inzé D (1998) Glutathione homeostasis in plants: implications for environmental sensing and plant development $J$ Exp Bot 49 649-667 https://academic.oup.com/jxb/article/49/ $321 / 649 / 450344 /$ Glutathione-homeostasis-in-plantsimplications-for

Mhamdi A, Hager J, Chaouch S, Queval G, Han Y, Taconnat L, Saindrenan P, Gouia H, Issakidis-Bourguet E, Renou J-P and Noctor G (2010) Arabidopsis GLUTATHIONE REDUCTASE1 plays a crucial role in leaf responses to intracellular hydrogen peroxide and in ensuring appropriate gene expression through both salicylic acid and jasmonic acid signaling pathways Plant Physiol 153 1144-1160 https://www.ncbi.nlm.nih.gov/pmc/articles/PMC2899936/

Mhamdi A, Han Y and Noctor G (2013) Glutathione-dependent phytohormone responses: Teasing apart signaling and antioxidant functions Plant Signal Behav 8 e24181 https:/ /www.ncbi.nlm.nih.gov/pmc/articles/PMC3907397/

Mohr P G and Cahill D M (2007) Suppression by ABA of salicylic acid and lignin accumulation and the expression of multiple genes, in Arabidopsis infected with Pseudomonas syringae pv. tomato Func Integr Genomics 7 181-191 https://dx.doi.org/10.1007/s10142-006-0041-4

Mou Z, Fan W and Dong X (2003) Inducers of plant systemic acquired resistance regulate NPR1 function through redox changes Cell 113 935-944 http://www.sciencedirect.com/ science/article/pii/S009286740300429X

Noctor G, Arisi A-C M, Jouanin L and Foyer C H (1998) Manipulation of glutathione and amino acid biosynthesis in the chloroplast Plant Physiol 118 471-482 http:// www.plantphysiol.org/content/118/2/471

Noctor G and Foyer C H (1998) ASCORBATE AND GLUTATHIONE: Keeping active oxygen under control Annu Rev Plant Physiol Plant Mol Biol 49 249-279 http:// www.annualreviews.org/doi/full/10.1146/annurev.arplant. 49.1.249? url_ver=Z39.88-2003\&rfr_id=ori\%3Arid $\%$ 3Acrossref.org \&rfr_dat $=$ cr_pub\%3Dpubmed

Ogawa K (2005) Glutathione-associated regulation of plant growth and stress responses Antioxid Redox Signal 7 973$981 \mathrm{http}: / /$ online.liebertpub.com/doi/abs/10.1089/ ars.2005.7.973

Parisy V, Poinssot B, Owsianowski L, Buchala A, Glazebrook J and Mauch F (2007) Identification of PAD2 as a gammaglutamylcysteine synthetase highlights the importance of 
glutathione in disease resistance of Arabidopsis Plant $J 49$ 159-172 http://onlinelibrary.wiley.com/doi/10.1111/j.1365313X.2006.02938.x/abstract

Paudel J, Copley T, Amirizian A, Prado A and Bede J C (2013) Arabidopsis redox status in response to caterpillar herbivory Front Plant Sci 4113 https://www.ncbi.nlm.nih. gov/pmc/articles/PMC3644638/

Penninckx I A, Thomma B P, Buchala A, Métraux J P and Broekaert W F (1998) Concomitant activation of jasmonate and ethylene response pathways is required for induction of a plant defensin gene in Arabidopsis Plant Cell 102103 2113 https://www.ncbi.nlm.nih.gov/pmc/articles/ PMC143966/

Pieterse C M J, Leon-Reyes A, Van der Ent S and Van Wees S C $M$ (2009) Networking by small-molecule hormones in plant immunity Nat Chem Biol 5 308-316 https:// www.nature.com/nchembio/journal/v5/n5/full/ nchembio.164.html

Reymond P and Farmer E E (1998) Jasmonate and salicylate as global signals for defense gene expression Curr Opin Plant Biol 1 404-411 http://www.sciencedirect.com/science/ article/pii/S1369526698802641

Roetschi A, Si-Ammour A, Belbahri L, Mauch F and MauchMani B (2001) Characterization of an ArabidopsisPhytophthora pathosystem: Resistance requires a functional PAD2 gene and is independent of salicylic acid, ethylene and jasmonic acid signalling Plant J 28 293-305 http://citeseerx.ist.psu.edu/viewdoc/download?doi= 10.1.1.515.1273\&rep=rep1\&type $=$ pdf

Saisavoey T, Thongchul N, Sangvanich P and Karnchanatat A (2014) Effect of methyl jasmonate on isoflavonoid accumulation and antioxidant enzymes in Pueraria mirifica cell suspension culture J Med Plants Res 8 401-407 http:/ /www.academicjournals.org/journal/JMPR/article-abstract/ 6C1879545356

Schlaeppi K, Bodenhausen N, Buchala A, Mauch F and Reymond P (2008) The glutathione-deficient mutant pad2-1 accumulates lower amounts of glucosinolates and is more susceptible to the insect herbivore Spodoptera littoralis Plant J 55 774-786 http://onlinelibrary.wiley.com/doi/ 10.1111/j.1365-313X.2008.03545.x/abstract

Shan C and Liang Z (2010) Jasmonic acid regulates ascorbate and glutathione metabolism in Agropyron cristatum leaves under water stress Plant Sci 178 130-139 http:// www.sciencedirect.com/science/article/pii/ S0168945209002994

Simon U K, Polanschütz L M, Koffler B E and Zechmann B
(2013) High resolution imaging of temporal and spatial changes of subcellular ascorbate, glutathione and $\mathrm{H}_{2} \mathrm{O}_{2}$ distribution during Botrytis cinerea infection in Arabidopsis PloS One 8 e65811 https://www.ncbi.nlm. nih.gov/pmc/ articles/PMC3673919/

Sinha R, Bhattacharyya D, Majumdar A B, Datta R, Hazra S and Chattopadhyay S (2013) Leaf proteome profiling of transgenic mint infected with Alternaria alternata J Prot 93 117-132 https://linkinghub.elsevier.com/retrieve/pii/ S1874-3919(13)00050-X

Smith I K, Kendall A C, Keys A J, Turner J C and Lea P J (1984) Increased levels of glutathione in a catalase-deficient mutant of barley (Hordeum vulgare L.) Plant Sci Lett 37 29-33 http://www.sciencedirect.com/science/article/pii/ 0304421184901986

Spoel S H, Koornneef A, Claessens S M C, Korzelius J P, Van Pelt J A, Mueller M J, Buchala A J, Métraux J-P, Brown R, Kazan K, Van Loon L C, Dong X and Pieterse C M J (2003) NPR1 modulates cross-talk between salicylateand jasmonate-dependent defense pathways through a novel function in the cytosol Plant Cell 15 760-770 https:/ /www.ncbi.nlm.nih.gov/pmc/articles/PMC150028/

Spoel S H and Loake G J (2011) Redox-based protein modifications: the missing link in plant immune signalling Curr Opin Plant Biol 14 358-364 http://www.sciencedirect. com/science/article/pii/S1369526611000197

Srivastava M K and Dwivedi UN (1998) Salicylic acid modulates glutathione metabolism in pea seedlings J Plant Physiol 153 409-414 http://www.sciencedirect.com/science/article/ pii/S0176161798801685

Stasolla C (2010) Glutathione redox regulation of in vitro embryogenesis Plant physiol biochem 48 319-327 http:// www.sciencedirect.com/science/article/pii/ S0981942809002228?via\%3Dihub

Stasolla C, Belmonte M F, Tahir M, Elhiti M, Khamiss K, Joosen R, Maliepaard C, Sharpe A, Gjetvaj B and Boutilier K (2008) Buthionine sulfoximine (BSO)-mediated improvement in cultured embryo quality in vitro entails changes in ascorbate metabolism, meristem development and embryo maturation Planta 228 255-272 http:// edepot.wur.nl/42194

Stasolla C, Belmonte M F, van Zyl L, Craig D L, Liu W, Yeung E C and Sederoff R R (2004) The effect of reduced glutathione on morphology and gene expression of white spruce (Picea glauca) somatic embryos J Exp Bot 55 695709 http://citeseerx.ist.psu.edu/viewdoc/download?doi= 10.1.1.320.8101\&rep=rep $1 \&$ type $=$ pdf 
Stroiñski A, Chadzinikolau T, Gi ¿ewska $\mathrm{K}$ and Zieleziñska M (2010) ABA or cadmium induced phytochelatin synthesis in potato tubers Biol Plant 54 117-120 https:// link.springer.com/article/10.1007/s10535-010-0017-z

Su T, Xu J, Li Y, Lei L, Zhao L, Yang H, Feng J, Liu G and Ren D (2011) Glutathione-indole-3-acetonitrile is required for camalexin biosynthesis in Arabidopsis thaliana Plant Cell 23 364-380 https://www.ncbi.nlm.nih.gov/pmc/articles/ PMC3051237/

Tada Y, Spoel S H, Pajerowska-Mukhtar K, Mou Z, Song J, Wang C, Zuo J and Dong X (2008) Plant immunity requires conformational changes of NPR1 via S-nitrosylation and thioredoxins Science 321 952-956 https://www.ncbi.nlm. nih.gov/pmc/articles/PMC3833675/

Thomma B P, Eggermont K, Penninckx I A, Mauch-Mani B, Vogelsang R, Cammue B P and Broekaert W F (1998) Separate jasmonate-dependent and salicylate-dependent defense-response pathways in Arabidopsis are essential for resistance to distinct microbial pathogens Proc Nat Acad Sci USA 95 15107-15111 http://www.pnas.org/ content/95/25/15107.full

Thomma B P, Penninckx I A, Broekaert W F and Cammue B P (2001) The complexity of disease signaling in Arabidopsis Curr Opin Immunol 13 63-68 http://www.sciencedirect. com/science/article/pii/S0952791500001837

Turner J G, Ellis C and Devoto A (2002) The jasmonate signal pathway Plant Cell 14 S153-S164 https://www.ncbi.nlm. nih.gov/pmc/articles/PMC151253/

Vanacker H, Lu H, Rate D N and Greenberg J T (2001) A role for salicylic acid and NPR1 in regulating cell growth in Arabidopsi Plant J 28 209-216 http://onlinelibrary. wiley.com/doi/10.1046/j.1365-313X.2001.01158.x/ abstract

Verberne M C, Hoekstra J, Bol J F and Linthorst H J M (2003) Signaling of systemic acquired resistance in tobacco depends on ethylene perception Plant J 35 27-32 http:// onlinelibrary.wiley.com/doi/10.1046/j.1365313X.2003.01778.X/abstract

Vlot A C, Klessig D F and Park S-W (2008) Systemic acquired resistance: the elusive signal(s) Curr Opin Plant Biol 11 436-442 http://www.sciencedirect.com/science/article/pii/ S1369526608000988

Vos M D, Zaanen W V, Koornneef A, Korzelius J P, Dicke M, Loon L C V and Pieterse C M J (2006) Herbivore-induced resistance against microbial pathogens in Arabidopsis Plant Physiol 142 352-363 http://www.plantphysiol.org/ content $/ 142 / 1 / 352$

Wang S-D, Zhu F, Yuan S, Yang H, Xu F, Shang J, Xu M-Y, Jia SD, Zhang Z-W, Wang J-H, Xi D-H and Lin H-H (2011) The roles of ascorbic acid and glutathione in symptom alleviation to SA-deficient plants infected with RNA viruses Planta 234 171-181 https://link.springer.com/ article/10.1007\%2Fs00425-011-1391-2

van Wees S C M, Chang H-S, Zhu T and Glazebrook J (2003) Characterization of the early response of Arabidopsis to Alternaria brassicicola infection using expression profiling Plant Physiol 132 606-617 http://www.plantphysiol.org/ content/132/2/606

Wei L, Wang L, Yang Y, Wang P, Guo T and Kang G (2015) Abscisic acid enhances tolerance of wheat seedlings to drought and regulates transcript levels of genes encoding ascorbate-glutathione biosynthesis Front Plant Sci 6458 https://www.ncbi.nlm.nih.gov/pmc/articles/PMC4485351/

Willekens H, Chamnongpol S, Davey M, Schraudner M, Langebartels C, Van Montagu M, Inzé D and Van Camp W (1997) Catalase is a sink for $\mathrm{H}_{2} \mathrm{O}_{2}$ and is indispensable for stress defence in $\mathrm{C}_{3}$ plants $E M B O J \mathbf{1 6}$ 4806-4816 https://www.ncbi.nlm.nih.gov/pmc/articles/PMC1170116/

Wingate V P, Lawton M A and Lamb C J (1988) Glutathione causes a massive and selective induction of plant defense genes Plant Physiol 87 206-210 https:/www.ncbi.nlm.nih. gov/pmc/articles/PMC1054726/pdf/plntphys006270214.pdf

Wünsche H, Baldwin I T and Wu J (2011) S-Nitrosoglutathione reductase (GSNOR) mediates the biosynthesis of jasmonic acid and ethylene induced by feeding of the insect herbivore Manduca sexta and is important for jasmonate-elicited responses in Nicotiana attenuata J Exp Bot 62 4605-4616 https://www.ncbi.nlm.nih.gov/pmc/articles/PMC3170554/

Xiang C and Oliver D J (1998) Glutathione metabolic genes coordinately respond to heavy metals and jasmonic acid in Arabidopsis Plant cell (USA) https://www.ncbi.nlm.nih. gov/pmc/articles/PMC144077/

Xiang C, Werner B L, Christensen E M and Oliver D J (2001) The biological functions of glutathione revisited in Arabidopsis transgenic plants with altered glutathione levels Plant Physiol 126 564-574 https://www.ncbi.nlm. nih.gov/pmc/articles/PMC111149/

Yasuda M, Ishikawa A, Jikumaru Y, Seki M, Umezawa T, Asami T, Maruyama-Nakashita A, Kudo T, Shinozaki K, Yoshida S and Nakashita H (2008) Antagonistic interaction between systemic acquired resistance and the abscisic acid-mediated 
abiotic stress response in Arabidopsis Plant Cell 201678 1692 http://www.plantcell.org/content/20/6/1678

Yoshida S, Tamaoki M, Ioki M, Ogawa D, Sato Y, Aono M, Kubo A, Saji S, Saji H, Satoh S and Nakajima N (2009) Ethylene and salicylic acid control glutathione biosynthesis in ozoneexposed Arabidopsis thaliana Physiol Plant 136 284-298 http://onlinelibrary.wiley.com/doi/10.1111/j.13993054.2009.01220.x/abstract

Zhang Z, Wang J, Chai R, Qiu H, Jiang H, Mao X, Wang Y, Liu F and Sun G (2015) An S-(hydroxymethyl) glutathione dehydrogenase is involved in conidiation and full virulence in the rice blast fungus Magnaporthe oryzae PloS One $\mathbf{1 0}$ e0120627 http://journals.plos.org/plosone/article?id $=10.1371$ journal.pone. 0120627

Zhu Y L, Pilon-Smits E A, Tarun A S, Weber S U, Jouanin L and Terry N (1999) Cadmium tolerance and accumulation in Indian mustard is enhanced by overexpressing gammaglutamylcysteine synthetase Plant Physiol 121 1169-1178 https://www.ncbi.nlm.nih.gov/pmc/articles/PMC59484. 